\title{
Strategic Role of Mobile Commerce (M-Commerce) Payment System: Establishing New Competitive Advantage
}

\author{
Haim Hilman Abdullah, Abdul Manaf Bohari, \\ Ari Warokka and Ashraf Abdussalam \\ College of Business - UUM, Malaysia
}

\begin{abstract}
A Mobile based payment system or m-commerce is an emerging issue of e-commerce in Malaysia. It is recognized by both academia and practitioners as one of the fastest growing and preferable medium of making business transactions. This study investigated the benefits of $\mathrm{m}$-commerce payment method, and services satisfaction on m-commerce providers. Respondents were those who had experienced using this mode of payment. The main objectives of the study were; a) to determine the level of $\mathrm{m}$-commerce awareness in Malaysia; b) to determine the level of $\mathrm{m}$ commerce payment system usage among Malaysian; c) to determine the level of m-commerce payment environment among Malaysian; and d) to determine the relationship between payment system and payment environment toward m-commerce services satisfaction. The results show that $\mathrm{m}$-commerce is another tool that is both highly intangible and possesses specific characteristics. It can be developed and made as another avenue for firms to create competitive advantage.
\end{abstract}

Keyword: Mobile Commerce, Payment Systems

\section{Introduction}

Basically, online payment processing lets customers buy online, offline, and over mobile phone devices. Advancement of ICT has made online payment become one of the most popular modes of payments. Online payment system of e-commerce covers different payment mechanisms, which certainly affect firms' business practices. Such scenario certainly leads to the need for discussion on drivers and impediments of particular payment systems, which include issues related to business policy. Specifically, the analyses are related to development and contribution of online payment systems as well as future issues and challenges. Firms who have clear and strategic approaches on addressing these matters should be able to serve their customers better. For that reason, some studies have been conducted, as those done by Accenture. (2001); European Institute for Research and Strategic (1991); Morgan Stanley and Dean Witter (2000); and Morrison (2001), specifically for better understanding of these issues.

For example, most national and international online payments are using credit card. Some estimates over $90 \%$ of all e-commerce payment transactions were made through credit card. However some countries used debit cards. Apart form that, other factors like mediating services, other mobile payment systems and electronic currency could be influential and need to be 
considered too. Contemporary issues of online payment systems of e-commerce include different payment mechanisms, security and the extent to which these different systems are used. To know such issues would enable firms to develop better online transactions. All these somehow ignite the pros and cons on using mobile payments. In many cases, m-commerce and the wireless Internet have been the victims of overexcited speculation (Darling, 2001). Among 1,700 people surveyed in spring 2000 by Jupiter Communications, the majority said that they would not use nor pay for the wireless Web (Lindsay, 2000).

Mobile operators have a key role in $\mathrm{m}$ commerce. They are the owner and manager of the networks that link m-commerce offers to potential customers. Basically they have vast experience in prepaid and post paid billing, and knowledge about essential issues, such as economic reconciliation for roaming customers. They also provide the robust and scalable networks required for securing $\mathrm{m}$ commerce transactions. So, working with partners such as Alcatel should enable mobile based operators to speed up the process to secure payment solutions via mcommerce. Alcatel-Lucent (2007) reported that $\mathrm{m}$-commerce is a lucrative-and growingmarket. According to the ARC Group, about 57 million people worldwide spent US\$ 2.3 billion in 2002 on m-commerce purchases and the number grew up to 546 million users with total spent of US\$39.3 billion in 2007 . However, the ability of m-commerce is still questionable, with some users not stratified with certain aspects of it. Monica (2000) mentioned that Wireless Application Protocol (WAP) services were disappointing, particularly in Northern Europe countries, where mobile communications are most advanced and consumers know well the limitations of the wireless Web. In addition, Cotlier, (2000) coined, contrary to conventional perspectives on m-commerce, that forward-thinking marketers should not view m-commerce as e-commerce with limitations, but rather as wireless in its own unique medium, with its own unique benefits.

However, success or failure of m-commerce services is influenced by many factors which include cooperation among players involved, the ability to provide users with simple and the convenient and trusted means of purchasing goods and services. Theoretically, mobile service providers play a key role in the m-commerce value chain due to its position at the centre of two or more parties involved in the transaction. With suitable payment solutions, they can deliver goods and services over present and future networks better. In fact, the lack of multiple mobile payment options may distort the growth of mobile content. This study investigated problems and issues in the micro payment system of m-commerce. Interestingly, this study could be one of its kinds and would significantly contribute in term of m-commerce and micro payment systems. Obviously, Nohria and Leestma (2001) believed that people will not shop with their phones in the same way they shop with PCs. Unleashing the value of $\mathrm{m}$ commerce requires understanding the role that mobility plays in people's lives today. That calls for a radical shift in thinking. This is support by Ramakrishnan (2001) who discussed that even though wireless technology is sometimes regarded as an enhancement tool rather than a brand new medium, successful players in the mcommerce market space must take a much broader view of the technology, the market, and potential consumers.

\section{Literature Review}

Basically, m-commerce is one of the business transactions where price or essential terms were negotiated over an online system such as an Internet, Extranet, Electronic Data Interchange (EDI) network, or electronic mail system. According to Johnson (2002), mcommerce is a natural enhance version of ecommerce that allows users to interact with other users or businesses in a wireless mode 
at anytime and anywhere. The rate of technology to be adobe is comparatively very high; therefore, participating companies work continuously together to nurture the growth of m-commerce. Ramakrishnan (2001) mentioned that mobile communication through cell phones is costly, and any additional services will attract extra charges. The reason is that establishing a mobile communication network requires heavy business investment with no government support. In fact, Lamont (2001) believed that $\mathrm{M}$-commerce carriers therefore must look for a great deal of business activity to generate revenues that justify the huge infrastructure investments.

According to Coursaris and Hassanein (2002), e-commerce is often referred to as buying and selling using the Internet. However, Schwartz (2002) describes mcommerce as a subset of e-commerce. It is a new platform of purchasing, selling, and exchanging of goods and services via wireless network. In addition, m-commerce is presently preferred especially for the sale of mobile phone ring-tones and games. Furthermore, 3G/UMTS services has enabled payment for location-based services such as maps, as well as video, and audio content, including full length music tracks (Gururajan, 2002). The wide accessibility of the Internet makes any e-commerce service globally available. The Web enables the search and delivery of rich information, and sophisticated electronic transaction processes can be integrated easily with backend enterprise information systems. In contrast, the delivery of m-commerce applications relies on private wireless communication carriers. These services are usually delivered to a specific region, and are rather simple, more personalized, locationspecific and time-sensitive. Since a mobile device usually accompanies a person wherever he or she goes, mobile services can be delivered to a person anywhere and anytime rather than to a fixed office or home. M-commerce therefore creates more of a perception of enhanced intimacy with consumers than other office-based distribution channels. Time sensitive, simple transactions such as movie ticket purchases, banking, and travel reservations are believed to be the key applications that will stimulate m-commerce (Lucas, 2001; \& Swartz, 2001).

In addition, mobile search solutions connect mobile users with advertisers and this will create great revenue to the mobile companies and to the companies that advertised their products via m-commerce. The network operator will also generate additional revenue through off portal traffic and it will also develop a new advertising channel. This service can be provided through SMS, WAP, 3G and I-mode front position of developing innovative packages that will be instrumental in driving additional revenue streams for network and brand partners (Cole, 2001). As examples, one of the M-Commerce applications is TMobile which allows customers to receive instant snapshots of traffic conditions based on their current location. Nohria and Leestma (2001) mentioned that m-commerce opportunities can be very significant, if investors understand consumer groups intimately and develop ubiquitous solutions that recognize the role that mobility plays in consumers' lives. In business services, Kunii (2001) cited not being forced to be hardwired enables a company's employees to remain connected while moving from office to office, or state to state; they can tap into the corporate network from airport lounges and hotel lobbies. For individual consumers, mobile devices basically allow them to keep in touch with their friends and families anywhere and anytime. For instance, videophone users can take pictures wherever they go and send them attached with short notes to friends while shopping, traveling, or simply hanging out.

Hassanein (2003) describes Malaysia as one of the fastest growing markets and there is a vast potential of m-commerce industry to fulfill the market interest in e-commerce. However, it requires establishing a wired infrastructure necessary to enable electronic transactions. To predict the potential of $\mathrm{m}$ - 
commerce then, it would be useful to examine the growth in e-commerce. Morrison (2001) believed that the emergence market with similar trend for wireless industry is increasing and would spur the development of $\mathrm{m}$-commerce.

\section{Problem Statements}

Firms using m-commerce were like others who continuously introduced new products and services. Such commitment would enlarge their market coverage and potential to reach greater levels of society. One innovative application of mobile technology is in the financial services sector. In many developing countries, m-commerce has not spread thoroughly especially in rural areas. This has led a large percentage of them to operate on cash basis only or outside the formal banking system. However, the proliferation of mobile services in some of these countries has created a unique opportunity for banks to provide financial services over the mobile network at least at major cities. In light of the growing size of international and national remittances, this opportunity could have significant implications (Wishart, 2006). Unfortunately, in reality, m-commerce is often a highly frustrating experience. Industry observers attribute this drawback to the immaturity of mobile technology, but they believe 3G (third generation wireless digital cellular telephone technology) networks could change the situation (Cohn, 2001). However, people in most developing countries are still sceptical on using m-commerce. This study will be investigating the factor affecting the payment requirement and problem face by $\mathrm{m}$ commerce.

Specifically the objectives of the study were; a) to determine the level of $\mathrm{m}$-commerce awareness in Malaysia; b) to determine the level of m-commerce payment system usage among Malaysian; c) to determine the level of m-commerce payment environment among Malaysian; and d) to determine the relationship between payment system and payment environment toward m-commerce services satisfaction.

\section{Research Methodology}

Figure 1 illustrate the research framework which clearly indicates two independent variables; a) payment system through $\mathrm{m}$ commerce; and b) micro payment environment.

\section{Independent Variable Dependent Variable}

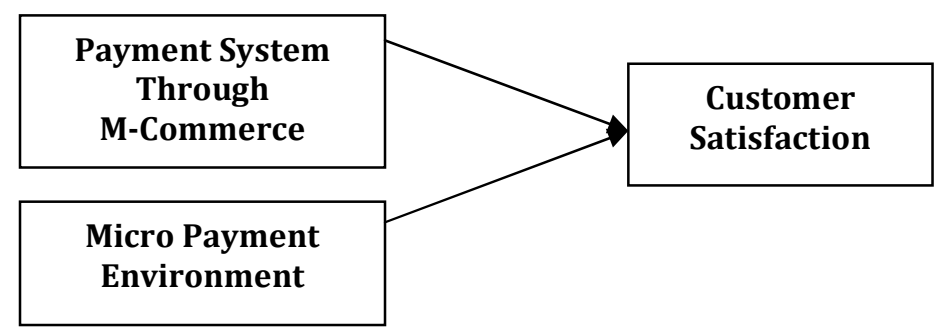

Fig. 1. Research Framework

The literature shows that the payment system through m-commerce has a high influence on customer satisfaction. This study is designed to measure whether the level of satisfaction among people who are using the payment system through mcommerce is similar to those developed countries. 


\section{Measurement}

This study used 5 point Likert scale that ranged from strongly agree to strongly disagree with focusing on the usage and implementation of m-commerce. Table 1 below shows the items of the questionnaire. The variable measures are to test to which extend m-commerce payments would influence the market and how it could enhance the performance of the Malaysian information technology based firms.

\section{Data Collection}

The data were collected form multiple economics and social backgrounds. However, the sample size was small because most of the respondents were using ordinary mobile phones which do not include $3 \mathrm{G}$ beside others and other functions which are related to m-commerce mobile phones. The data was collected from those who are using the mcommerce services.

The data were collected from those who are using the 3G mobile phone, PDA or smart phone. These respondents were members of our target population. These respondents were from diverse industrial backgrounds which represent different levels of knowledge and working experiences in the $\mathrm{m}$-commerce or e-commerce usage. The data was gathered within a month and Table 1 illustrates the items of every construct.

Table 1: Item of Measurement

\begin{tabular}{|l|l|}
\hline & Part 1: Benefits of M-Commerce Payment System \\
\hline 1 & Mobile Commerce payment system is convenient to use. \\
\hline 2 & Mobile Commerce payment software is user friendly. \\
\hline 3 & Mobile Commerce payment saves time. \\
\hline 4 & Mobile Commerce payment is cost effective solution. \\
\hline 5 & Mobile Commerce payment has decreased the barrier to enter the market place. \\
\hline 6 & Mobile Commerce payment saves human resource. \\
\hline 7 & Mobile Commerce technology is safe to use. \\
\hline
\end{tabular}

\begin{tabular}{|l|l|}
\hline & Part 2: M-Commerce Payment Environment \\
\hline 1 & Mobile Commerce Payment services are secure to use. \\
\hline 2 & Mobile Commerce Payment services are reliable to use. \\
\hline 3 & I was aware of Mobile Commerce Payment system. \\
\hline 4 & Mobile Commerce Payment device is expensive to use. \\
\hline 5 & Mobile Commerce service coverage is out of range. \\
\hline 6 & Mobile Commerce services are expensive from service provider. \\
\hline 7 & I do not trust the Mobile Commerce Payment through PDA device. \\
\hline
\end{tabular}

\begin{tabular}{|l|l|}
\hline & Part 3 : M-Commerce Services Satisfaction \\
\hline 1 & I am Satisfied with the Mobile commerce services. \\
\hline 2 & It enhances the performance of individual. \\
\hline 3 & I am Satisfied with the ease of use of software. \\
\hline 4 & I am Satisfied with the powerful Anti virus with in the device. \\
\hline 5 & I am Satisfied because it is the direct access to the market. \\
\hline 6 & I am Satisfied because it has very nice features. \\
\hline 7 & I am Satisfied with GPRS system. \\
\hline 8 & I am Satisfied with the price of device. \\
\hline 9 & I am Satisfied with the features. \\
\hline
\end{tabular}




\section{Results}

\section{Demographic Background}

Based on the survey, the male respondents were slight higher than the female ones as they represented 53.8 percent of the respondents. The results also indicated that 74.4 percent of the respondents are aged between 18-29 years old, followed by those aged between 30-35 years old years or 25.6 percent. In addition, 33.3 percent of the respondents were Malay while Indians and Chinese were holding 10.3 percent each and others held 46.2 percent. In terms of education, results show that 56.4 percent of the respondents were having master degree, 38.5 percent were having a bachelor degree and 6.1 percent with advanced diploma.

\section{Descriptive Statistic on Benefit of M-Commerce}

Table 2 describes respondents' perception on each of the items in the construct. Generally respondents did agree with all the items on benefits of m-commerce system. For example, the item "mobile commerce payment system is convenient to use" recorded 69.2 percent of respondents agreeing with the statement. The second item "mobile commerce payment software is user friendly" recorded 59.0 percent of respondents agreeing with the statement. The third item "Mobile Commerce payment saves time" recorded 53.8 percent of respondents agreeing with the statement. The fourth item "Mobile Commerce payment is cost effective solution" recorded 56.4 percent of respondents agreeing with the statement. The fifth item "Mobile Commerce payment has decreased the barrier to enter the market place" recorded 51.3 percent of the respondents agreeing with the statement. The sixth item "Mobile Commerce payment saves human resource" recorded 43.6 percent of the respondents agreeing with the statement. Meanwhile the final item "Mobile Commerce technology is safe to use" indicated 66.7 percent of the respondents agreeing with the statement. Overall, the level of benefits of m-commerce payment system is high which is with the value of mean 4.00 .

Table 2: Benefit of M-Commerce Payment System

\begin{tabular}{|c|c|c|c|c|c|c|c|}
\hline & & $\begin{array}{l}\text { Strongly } \\
\text { Disagree }\end{array}$ & Disagree & Neutral & Agree & $\begin{array}{l}\text { Strongly } \\
\text { Agree }\end{array}$ & Mean \\
\hline & & 1 & 2 & 3 & 4 & 5 & \\
\hline 1 & $\begin{array}{l}\text { Mobile Commerce payment } \\
\text { system is convenient to use. }\end{array}$ & 0 & 0 & 7.7 & 69.2 & 23.1 & 4.15 \\
\hline 2 & $\begin{array}{l}\text { Mobile Commerce payment } \\
\text { software is user friendly. }\end{array}$ & 0 & 0 & 17.9 & 59.0 & 23.1 & 4.05 \\
\hline 3 & $\begin{array}{l}\text { Mobile Commerce payment } \\
\text { saves time. }\end{array}$ & 0 & 0 & 20.5 & 53.8 & 25.6 & 4.05 \\
\hline 4 & $\begin{array}{l}\text { Mobile Commerce payment is } \\
\text { cost effective solution. }\end{array}$ & 0 & 2.6 & 25.6 & 56.4 & 15.4 & 3.85 \\
\hline 5 & $\begin{array}{l}\text { Mobile Commerce payment } \\
\text { has decreased the barrier to } \\
\text { enter the market place. }\end{array}$ & 0 & 5.1 & 17.9 & 51.3 & 25.6 & 3.97 \\
\hline 6 & $\begin{array}{l}\text { Mobile Commerce payment } \\
\text { saves human resource. }\end{array}$ & 0 & 2.6 & 15.4 & 43.6 & 38.5 & 4.18 \\
\hline 7 & $\begin{array}{l}\text { Mobile Commerce technology } \\
\text { is safe for use. }\end{array}$ & 0 & 2.6 & 25.6 & 66.7 & 5.1 & 3.74 \\
\hline & Overall benefits & & & & & & 4.000 \\
\hline
\end{tabular}




\section{Descriptive Statistic of M-Commerce Payment Environment}

Table 3 describe respondents' perception of each of the item in the construct. The first item, "Mobile Commerce Payment services are secure to use" recorded 35.9 percent of the respondents were neutral and agree with the statement. The second item "Mobile Commerce Payment services are reliable to use" recorded 28.2 percent of the respondents agree with the statement. The third item "I was aware of Mobile Commerce Payment system" recorded 38.5 percent of the respondents neutral with the statement. The fourth item "Mobile Commerce Payment device is expensive to use" recorded 43.6 percent of the respondents neutral with the statement. The fifth item "Mobile commerce service coverage is out of range" recorded 46.2 percent of the respondents neutral with the statement. The sixth item "Mobile Commerce services are expensive from service provider" recorded 38.5 percent of the respondents agree with the statement. The last item "I do not trust the Mobile Commerce Payment through PDA device" recorded 71.8 percent of the respondents agree with the statement. Overall the level of m-commerce payment environment was moderate with the value of mean 3.58.

\section{Descriptive Statistic of M-Commerce Services Satisfaction}

Table 4 describes respondents' perception of each of the item in the construct. The findings indicate that the first item "I am satisfied with the mobile commerce services" recorded 56.4 percent of the respondents agreeing with the statement. The second item "It enhances the performance of individual" recorded 48.7 percent of the respondents agreeing with the statement. The third item "I am satisfied with the ease of use of software" recorded 69.2 percent of the respondents agreeing with the statement. The fourth item "I am satisfied with the powerful antivirus within the device" recorded 46.2 percent of the respondents agreeing with the statement. The fifth item "I am satisfied because it is the direct access to the market" recorded 53.8 percent of the respondents agreeing with the statement. The sixth item "I am satisfied because it has very nice features" recorded 64.1 percent of the respondents agreeing with the statement. The seventh item "I am satisfied with GPRS system" recorded 30.8 percent of the respondents strongly agreeing with the statement. The eighth item "I am satisfied with the price of device" recorded 46.2 percent of the respondents agreeing with the statement. The final item "I am satisfied with the features" recorded 69.2 percent of the respondents agreeing with the statement. Overall level of services satisfaction was moderate with the value of mean 3.781. 
Table 3: M-Commerce Payment Environment

\begin{tabular}{|c|c|c|c|c|c|c|c|}
\hline & & $\begin{array}{l}\text { Strongly } \\
\text { Disagree }\end{array}$ & Disagree & Neutral & Agree & $\begin{array}{l}\text { Strongly } \\
\text { Agree }\end{array}$ & Mean \\
\hline & & 1 & 2 & 3 & 4 & 5 & \\
\hline 1 & $\begin{array}{l}\text { Mobile Commerce Payment } \\
\text { services are secure to use }\end{array}$ & 5.1 & 10.3 & 35.9 & 35.9 & 12.8 & 3.41 \\
\hline 2 & $\begin{array}{l}\text { Mobile Commerce Payment } \\
\text { services are reliable to use. }\end{array}$ & 12.8 & 12.8 & 20.5 & 28.2 & 25.6 & 3.41 \\
\hline 3 & $\begin{array}{l}\text { I was aware of Mobile } \\
\text { Commerce Payment system. }\end{array}$ & 0 & 0 & 38.5 & 30.8 & 30.8 & 3.92 \\
\hline 4 & $\begin{array}{l}\text { Mobile Commerce Payment } \\
\text { device is expensive to use. }\end{array}$ & 0 & 12.8 & 43.6 & 33.3 & 10.3 & 3.41 \\
\hline 5 & $\begin{array}{l}\text { Mobile Commerce service } \\
\text { coverage is out of range. }\end{array}$ & 0 & 5.1 & 46.2 & 33.3 & 15.4 & 3.59 \\
\hline 6 & $\begin{array}{l}\text { Mobile Commerce services } \\
\text { are expensive from service } \\
\text { providers. }\end{array}$ & 0 & 12.8 & 30.8 & 38.5 & 17.9 & 3.62 \\
\hline 7 & $\begin{array}{l}\text { I do not trust the Mobile } \\
\text { Commerce Payment through } \\
\text { PDA device. }\end{array}$ & 0 & 2.6 & 23.1 & 71.8 & 2.6 & 3.74 \\
\hline & $\begin{array}{l}\text { Overall payment } \\
\text { environment }\end{array}$ & & & & & & 3.58 \\
\hline
\end{tabular}

Table 4: M-Commerce Services Satisfaction

\begin{tabular}{|c|c|c|c|c|c|c|}
\hline & $\begin{array}{l}\text { Strongly } \\
\text { Disagree }\end{array}$ & Disagree & Neutral & Agree & $\begin{array}{l}\text { Strongly } \\
\text { Agree }\end{array}$ & Mean \\
\hline & 1 & 2 & 3 & 4 & 5 & \\
\hline $\begin{array}{l}1 \text { I am Satisfied with the Mobile } \\
\text { commerce services. }\end{array}$ & 0 & 0 & 17.9 & 56.4 & 25.6 & 4.08 \\
\hline $\begin{array}{l}2 \text { It enhances the performance of } \\
\text { individual. }\end{array}$ & 0 & 2.6 & 33.3 & 48.7 & 15.4 & 3.77 \\
\hline $\begin{array}{l}3 \text { I am Satisfied with the ease of } \\
\text { use of software. }\end{array}$ & 0 & 2.6 & 15.4 & 69.2 & 12.8 & 3.92 \\
\hline $\begin{array}{l}4 \text { I am Satisfied with the powerful } \\
\text { Antivirus within the device. }\end{array}$ & 0 & 5.1 & 43.6 & 46.2 & 5.1 & 3.51 \\
\hline $\begin{array}{l}5 \text { I am Satisfied because it is the } \\
\text { direct access to the market. }\end{array}$ & 0 & 2.6 & 30.8 & 53.8 & 12.8 & 3.77 \\
\hline $\begin{array}{l}6 \text { I am Satisfied because it has very } \\
\text { nice features. }\end{array}$ & 0 & 0 & 23.1 & 64.1 & 12.8 & 3.90 \\
\hline 7 I am Satisfied with GPRS system. & 0 & 12.8 & 28.2 & 28.2 & 30.8 & 3.77 \\
\hline $\begin{array}{l}8 \text { I am Satisfied with the price of } \\
\text { device. }\end{array}$ & 0 & 5.1 & 43.6 & 46.2 & 5.1 & 3.51 \\
\hline 9 I am Satisfied with the features. & 0 & 0 & 25.6 & 69.2 & 5.1 & 3.79 \\
\hline Overall services satisfaction & & & & & & 3.781 \\
\hline
\end{tabular}




\section{Results Analysis on Hypothesis}

\section{Hypothesis Testing the Demographic} Factors (Gender)

Ho1 = M-commerce services satisfaction do not differ between gender

Table 5 illustrates the results of the t-test of the hypothesis, which indicated the difference in the mean of 3.778 and 3.784 with standard deviation of 0.429 and 0.384 for male and female on m-commerce services satisfaction, is not significant i.e. $<0.05$, so null hypothesis (Ho1) is accepted. This means that there is no significant difference between male and female towards mcommerce services.

Table 5: Independent Samples Test between Genders

\begin{tabular}{ccccccc}
\hline & $\mathrm{N}$ & Mean & $\begin{array}{c}\text { Standard } \\
\text { Deviation }\end{array}$ & $\begin{array}{c}\text { Mean } \\
\text { Difference }\end{array}$ & $\mathrm{T}$ & Significance \\
\hline Male & 21 & 3.778 & 0.42889 & -0.00617 & - & 0.963 \\
\hline Female & 18 & 3.784 & 0.38390 & & & \\
\hline
\end{tabular}

\section{Hypothesis Testing the Demographic Factors (Age)}

Ho2 = M-commerce services satisfaction do not differ between age

Table 6 illustrates the results of the t-test of the hypothesis, which indicated that the difference in the mean of 3.85 and 3.58 with standard deviation of 0.400 and 0.354 for age between 18-29 years old and age between 30-35 years old on m-commerce services satisfaction, is not significant i.e. $<0.05$, so null hypothesis (Ho2) is accepted. This means that there is no significant difference between different ages towards m-commerce services.

Table 6: Independent Samples T-Test between Age and M-Commerce Services Satisfaction.

\begin{tabular}{|c|c|c|c|c|c|c|}
\hline Age & $\mathrm{N}$ & Mean & $\begin{array}{l}\text { Standard } \\
\text { Deviation }\end{array}$ & $\begin{array}{c}\text { Mean } \\
\text { Difference }\end{array}$ & $\mathrm{T}$ & Significance \\
\hline $\begin{array}{c}18- \\
29\end{array}$ & 29 & 3.8506 & 0.40092 & 0.27280 & 1.907 & 0.064 \\
\hline $\begin{array}{c}30- \\
35\end{array}$ & 10 & 3.5778 & 0.35447 & & & \\
\hline
\end{tabular}

\section{Hypothesis Testing the Demographic Factors (Education)}

Ho3 = M-commerce services satisfaction do not differ between highest education level

The results in Table 7 indicate the result of ANOVA, which is the highest education factor, that the $\mathrm{F}$ value 1.032 is not significant i.e. $<0.05(p=0.367)$, so null hypothesis (Ho3) is accepted. This means that there is no significant difference between the highest education factors on $\mathrm{m}$-commerce services satisfaction. 
Table 7: One-Way ANOVA between Highest Education Levels with M-Commerce Services Satisfaction

\begin{tabular}{lll}
\hline M-commerce services satisfaction & F & Significant \\
\hline Highest Education Level & 1.032 & 0.367 \\
\hline
\end{tabular}

\section{Hypothesis Testing the Relationship between the Benefits of M-Commerce Payment System and M-Commerce Services Satisfaction}

Ho4 = There is no significant relationship between benefits of $\mathrm{m}$-commerce payment system and m-commerce services satisfaction

Table 8 below illustrates that both variables are interval. Based on the Pearson
Correlation test, the results show significant and positive correlation between benefits of $\mathrm{m}$-commerce payment system and $\mathrm{m}$ commerce services satisfaction with a significant level of 0.001 , so the null hypothesis (Ho4) is rejected. This means that the benefits of $\mathrm{m}$-commerce payment system and $\mathrm{m}$-commerce services satisfaction are related.

\section{Table 8: Correlations between Benefits of M-Commerce Payment System and M-Commerce} Services Satisfaction

\begin{tabular}{llc}
\hline & Pearson Correlation (r) & Significant \\
\hline $\begin{array}{l}\text { Benefits of m-commerce payment } \\
\text { system and m-commerce services } \\
\text { satisfaction }\end{array}$ & 0.531 & 0.001 \\
\end{tabular}

\section{Hypothesis Testing the Relationship between M-Commerce Payment Environment and M-Commerce Services Satisfaction}

Ho5 = There is no significant relationship between $\mathrm{m}$-commerce payment environment and m-commerce services satisfaction

Table 9 illustrates that both variables are interval and based on the Pearson
Correlation test, the results show no significant correlation between m-commerce payment environment and m-commerce services satisfaction with a value of 0.953 , so the null hypothesis (Ho5) is accepted. This means that m-commerce payment environment and m-commerce services satisfaction are not related. 
Table 9: Correlations between M-Commerce Payment Environment and M-Commerce Services Satisfaction

\begin{tabular}{llc}
\hline & Pearson Correlation (r) & Significant \\
\hline $\begin{array}{l}\text { M-commerce payment } \\
\text { environment and m-commerce }\end{array}$ & 0.010 & 0.953 \\
services satisfaction & & \\
& & \\
& &
\end{tabular}

\section{Hypothesis Testing the Influence of the Benefits of M-Commerce Payment System and M-Commerce Payment Environment on M-Commerce Services Satisfaction}

Ho6: The two independent variables (benefits of m-commerce payment system and m-commerce payment environment) will not significantly explain the variance in $\mathrm{m}$ commerce services satisfaction.

Table 10 illustrates that the regression results of the two independent variables are against m-commerce services satisfaction. The first table in the output 'Model Summary' shows the $\mathrm{R}$ square of 0.305 , which means that $\mathrm{m}$-commerce service satisfaction, are explained by the two independent variables. This means that 30.5 per cent of the two variables influence the dependent variable. Furthermore, the ANOVA table shows that the $F$ value of 7.893 is significant at the 0.001 level, so null hypothesis (Ho6) is rejected.

Table 10: Multiple Regression Analysis of M-Commerce Services Satisfaction Regression Model Summary

\begin{tabular}{|c|c|c|c|c|}
\hline Model & & $\mathrm{R}$ & \multicolumn{2}{|c|}{ R Square } \\
\hline 1 & & 0.552 & \multicolumn{2}{|c|}{0.305} \\
\hline \multicolumn{5}{|c|}{ Anova } \\
\hline Model & & $\mathrm{F}$ & \multicolumn{2}{|c|}{ Significant } \\
\hline 1 & & 7.893 & \multicolumn{2}{|c|}{0.001} \\
\hline \multicolumn{5}{|c|}{ Coefficients } \\
\hline Model & B & Beta & $\mathrm{T}$ & Significant \\
\hline Constant & 1.268 & & 1.901 & 0.065 \\
\hline Benefit & 0.527 & 0.530 & 3.812 & 3.812 \\
\hline Payment & 0.113 & 0.150 & 1.082 & 1.082 \\
\hline
\end{tabular}

\section{Discussion}

Developing competitive advantage for $\mathrm{m}$ commerce via marketing strategies is a complex issue. M-commerce is a tool that is both highly intangible and possesses specific characteristics. This research has identified one critical success factor that appears important to m-commerce services satisfaction, which is m-commerce payment system positively associated with mcommerce services satisfaction with a percentage of 30.5 percent.

Successful adoption of m-commerce should enable firms to establish another core competency than its rivals. The result of this study on branding and positioning strategies 
via m-commerce goes along with past research findings which are able to become another avenue for firms to create or establish new competitive advantage in service industries (Aaker, 1991; Hall, 1992, 1993).

The development of a broad and a deep software and the development of programs in creating differentiation through the $\mathrm{m}$ commerce market, is consistent with past literature since the development of competitive advantage for service satisfaction is highly associated with the development of "Resources/skills stock" (Dierickx and Cool, 1989; Bharadwaj et al., 1993). By this process, the organisation could create and achieve another competitive lead over its competitors.

\section{Conclusion and Future Research}

Services satisfaction, the use of the mcommerce payment system and environment toward m-commerce initiatives would not be successful if either one of them is lacking. Despite the focus on m-commerce in this study, the use of the system provided by others is also important. Future research is needed to examine the factors associated with the use of m-commerce by others as well as continuing the efforts to understand the m-commerce. Moreover, taking $\mathrm{m}$ commerce as a focus does not suggest that face-to-face $\mathrm{m}$-commerce is not important. In fact, we need more research to advance our understanding in terms of how these two approaches can reinforce each other.

The findings of this study have some important managerial implications. First, the positive relationship identified between mcommerce and its payment system and payment environment supports a long-held proposition running through the mcommerce literature which states that the attainment of organizational goals is determined by satisfying the needs of customers more efficiently and effectively than rivals (Kotler and Armstrong, 1996). Mcommerce emphasizes the need to attain market position by developing quality product specifically targeted to well-defined m-commerce segments which are backed up by the customer support.

The successful implementation of any mcommerce strategy requires that organizations strike the right balance between tight and loose control mechanisms, and formal and informal modes of communication to maintain a degree of flexibility and responsiveness appropriate to the speed of change manifested within their served to the customer. Above and beyond these practical m-commerce initiatives, there is some evidence in this study to suggest that the benefits of payment system play an essential role in enhancing the $\mathrm{m}$-commerce services satisfaction.

In conclusion the benefits of payment system and payment environment should become strategic agenda for firms that wanted to use $\mathrm{m}$-commerce services satisfaction as one of their tools to establish competitive advantage. However, to build such an advantage requires firms to get engaged with a continuous knowledge enhancement programme. By doing so, a firm will have a better chance to increase the quality of services it provides to customers and finally will make it the platform to create new competitive advantage.

\section{References}

Accenture. (2001). 'The Future of Wireless: Different than you Think, Bolder than you Imagine,' [Online], [Retrieved February 12, 2007],

http://www.accenture.com/xdoc/en/ideas/i sc

Alcatel-Lucent (2007). M-Commerce is Moving. [Online], [Retrieved February 13, 2007], http://www.alcatel-lucent.com www.alcatel-lucent.com

Cavoukian, A. \& Gurski. M. (2002). 'Privacy in a Wireless World,' [Online], [Retrieved February 14, 2007], http://www.ipc.on.ca 
Chou, Y. , Lee, C. \& Chung, J. (2000). "Understanding M-Commerce Payment Systems Through The Analytic Hierarchy Process," Journal of Business Research. pp. 1423- 1430

Cohn, M. (2001). 'Full Beam,' [Online], [Retrieved February 14, 2008], http://www.m-commerceworld.com/articles

Cotlier, M. (2000). 'Wide Wireless World,' Catalog Age; New Canaan; Dec 2000, pp. 1617.

Coursaris, C., Hassanein, K. \& Head, M. (2003). "M-commerce in Canada: An Interaction Framework for Wireless Privacy," Canadian Journal of Administrative Sciences. Halifax: Mar 2003, 20 (1) p. 54

Darling, A. (2001). 'Waiting for the MCommerce Explosion,' Telecommunications; Dedham; Feb 2001; International Edition, Vol. 35, No. 2, pp. 34-38

European Institute for Research and Strategic. (1991). 'EURESCOM,' Studies in Telecommunications Schloss,

Wolfsbrunnenweg, Heidelberg, German.

Gururajan, R. (2002). 'Mobile Computing: Security Risks,' The 23rd World Congress on the Management of Electronic Commerce, Hamilton.

Johnson, D. (2002). 'Securing your PDA,' [Online], [Retrieved February 22, 2007], http://www.idg.net/ic.

Katrin Penzel (2006). 'Mobile Payments and Keitai Credit-Disruptive Innovation,' [Online], [Retrieved January 25, 2007], http://www.eurotechnology.com

Kim, M.-A., Lee, H.-K., Kim, S.-W., Lee, W.-H. \& Kang, E.-K. (2002). "Implementation of Anonymity-Based E-Payment System for Mcommerce," Communications, Circuits and Systems and West Sino Expositions, IEEE 2002 International Conference. Chung-Ang Univ., Seoul, South Korea: Vol, 1, Pg 363- 366
Kuhn, Thomas S. (1970). The Structure of Scientific Revolutions (2nd ed), Großdruck: Chicago.

Kunii, I. M. (2001). 'Japan: A Wonderland for the Wireless Crowd,' Business Week; New York; Nov 12, 2001; No.3757, pp.73

La Monica, M. (2000). 'Injecting Reality into M-Commerce Buzz,' InfoWorld; Framingham; Oct 23, 2000; Vol. 22, No. 43, pp.5

Lamont, D. (2001). "Conquering the Wireless World, the Age of M-Commerce," Capstone Publishing Limited (A Wiley Company).

Leiner, B. M., Cerf, V. G., Clark, D. D., Kahn, R. E., Kleinrock, L., Lynch, D.C., Postel, J., Roberts, L.G. \& Wolff, S. (2002). 'A Brief History of the Internet,' [Online], [Retrieved January 15, 2007], http://www.isoc.org/intemet/history/brief. html

Lindsay, G. (2000). 'In Search of: Who Wants M-Commerce,' Fortune; New York; Oct 16, 2000; Vol.142, No.9, pp.398-400

Lucas, P. (2001). 'M-commerce Gets Personal,' Credit Card Management; New York; Apr 2001, Vol. 14, No.1, pp.24-30

Mobile Commerce. (2007). 'Extends Monetised Mobile Search to all WAP Site Owners M2 Presswire,' Coventry: Feb 21, 2007.pg. 1

Morrison, D. (2001). 'Technology Push and Customer Pull: The Wireless Internet Comes of Age,' Presentation at McMaster University, Hamilton.

Nohria, N. \& Leestma, M. (2001). "A Moving Target: The Mobile-Commerce Customer," Mit Sloan Management Review; Cambridge; Spring 2001; Vol. 42, No. 3, pp.104

Nielsen, J. (2000). "Designing Web Usability: The Practice of Simplicity," Indianapolis, IN: New Riders Publishing. 
Ramakrishnan, J. (2001). 'WWWireless Wonder,' Corporate Location; Milton Keynes; Mar/Apr 2001; pp.60-61

Richard, C. (2007). "Mobile Payment Forum to Hold Spring Meeting in San Diego Wireless News," [Online], [Retrieved January 25, 2007], http://www.highbeam.com

Richardson (2007). 'M-Commerce: MPayment Systems 2006,' [Online], [Retrieved February 26, 2007], http:// www.witiger.com/ecommerce

Rogers Communications. (2002). 'Network Coverage Info,' [Online], [Retrieved January 10, 2007], http:/www.shoprogers.com

Schwartz, E. (2000). "Fixing a Security Hole When the Rain Gets in: Two-Zone Encryption Limits Wireless Usage," InfoWorld. [Online], [Retrieved January 25, 2007], http://www.infoworld.com/ articles

Shay, S. (1999). Investing in the Web (Interview with Guy Kawasaki),' In: $\mathrm{CIOWeb}$ Business. [Online], [Retrieved January 17, 2007], http://www.cio.com.

Swartz, N. (2001). 'Hot \& Cold: M-Commerce Opportunities,' Wireless Review; Overland Park; Mar 15, 2001; Vol. 18, No. 6, pp.32-38

The Hindu Group. (2002). "Mobile Commerce: Automatic Payment Systems," Online edition of India's National Newspaper. [Online], [Retrieved January 28, 2007], http://www.hindu.com/thehindu/biz/2002

Wishart, N. (2006). 'Micro-Payment Systems and their Application to Mobile Networks,' Washington, DC: infoDev / World Bank.

Witter, M. S. D. (2000). 'B2B Internet Report,' April 2000. [Online], [Retrieved February 22, 2007],

http://www.morganstanley.com/institutiona l/techresearch 